\title{
MJN \\ NURSES' COMPLIANCE WITH INFECTION CONTROL MEASURES AND BARRIERS TO PRECAUTIONS IN THE DELIVERY ROOM
}

\author{
Inaam Abdelati ${ }^{*}$, Maha Ali², Yousif, A. ${ }^{3}$, Amany El-berdan ${ }^{4}$ \\ ${ }^{1}$ Maternity, Gynecology and Obstetrics, Nursing Faculty of Nursing, Port-Said University, Egypt \\ ${ }^{2}$ Maternity, Obstetric \& Gynecological Nursing, Faculty of Nursing, Port-Said University, Egypt \\ ${ }^{3}$ Woman's Health \& Midwifery Nursing, Faculty of Nursing, Mansoura University, Egypt \\ ${ }^{4}$ Medical Surgical Nursing, Faculty of Nursing, Port-Said University, Egypt \\ *Corresponding Author's Email: gogo_na 100@yahoo.com
}

\begin{abstract}
Background: Nurses play crucial role in avoiding hospital procured infections, by guaranteeing that all viewpoints of their nursing practice is evidence based and also through nursing research and understanding instruction. Aim: The study aimed to evaluate the nurse's compliance with infection control measures and barrier to precautions in delivery room. Methods: Research design: An exploratory design had been chosen for carrying out our paper. Setting: The study was carried out in four hospitals in Damietta governorate. Subjects: About 51 on duty nurses were chosen at the time of the study. Tools of data collection: Data were collected using self-administered questioners. Results: Findings revealed the existence of poor standard of precautions (100\%). This was related to age, education level, work involvement experience, and compliance with standard safety measures and precautions at $p<0.05$. At the same time significant relation between training courses and compliance to standard precautions was $p<0.05$. Conclusion: The nurses in the current study faced a lot of barriers that posed a hindrance in implementing the infection control measures, such as in situations like, emergency situation, lack of equipment and supplies, lack of infection control measures, lack of periodical infection and control training course. Recommendations: Strategic plan to overcome obstacles and barriers that hinder nurses' compliance with infection control measures should be conducted. It is essential to consider the national standards of infection prevention adopted by the Ministry of Health in delivery room of all hospital in Damietta Governorate.
\end{abstract}

Keywords: Compliance, Standard Precaution, Infection control, Delivery Room

\section{INTRODUCTION}

Infection is defined as an invasion of body tissues by disease-causing microorganisms, their multiplication could produce the toxins that leads to harmful effect to the body tissues. Maternal sepsis is one of the main reasons behind 75,000 deaths each year, for the most part in low-income nations, and accounts for $14 \%$ of maternal mortality in Asia and Africa. Also, in most reviews, maternal death rates associated with infection range from $4-8 \%$, or approximately that is 0.6 maternal deaths per 100,000 live births (Kaïret et al., 2017).
A pregnancy-related mortality surveillance by the centres for disease control and prevention (CDC) indicated that infection accounted for about $11.6 \%$ of all deaths following by pregnancy that resulted in a live birth, stillbirth, or ectopic (Friedman et al., 2017). Mothers are vulnerable to get infections from the surrounding environment of the Hospital. Mothers might be exposed to infection due to multiple examinations by health care providers during the process of labor Health care, particularly nurses might acquire an infection during the nursing care because of occupational exposure to microorganisms and also due to uncovered blood 
borne diseases by pathogens such as human immune insufficiency virus (HIV), hepatitis B and hepatitis C infections through sharp wounds and through direct contacts with blood and other body liquids (Ahmed, 2015).

Compliance had been defined within health care settings as the degree to which certain conduct (for eg. Obeying physician's orders or changing their lifestyle) was in line with the understanding the instruction of the physicians or wellbeing care counsel (Sax, Perneger \& Hugonnet, 2011). Compliance might be impacted or controlled by various factors such as culture, financial condition, social components, self-efficacy and other information that are not recorded. Rules that direct an individual's conduct exist in an assortment of settings (taking into account the wellbeing care settings) but individuals did not comply with them continuously (Hazavehei, Taghdisi \& Saidi, 2011)

Infection control is a more substantial area of concern in Labor and delivery room. The medical attendants are the key individuals causing contamination among control group in healing centers. Hence, medical caretakers ought to have proper information and abilities in the field of contamination control (Morgan, Wenzel \& Bearman, 2017). As revealed from the prove, the correct compliance with Standard Safety measures can secure wellbeing among care laborers from different sorts of blood borne diseases, Clinic Procured Contaminations counting pneumonia and intravascular catheter diseases (Singh et al., 2011)

Assumed that 38.2\% had reasonable information about standard safeguard measures, and $37.8 \%$ had great information. $24.0 \%$ of the examined test had destitute information level. Concurring to their compliance 52.9\% had reasonable level, $45.6 \%$ had great level and 1.5\% had destitute level (Tait et al., 2011).

\section{Significance of the study}

The maternal mortality rate from infection is higher. The world health organization (WHO) estimates that approximately 210 million women become pregnant each year and that 529,000 die from complications related to pregnancy. In the immediate post-partum period, sepsis is the common causes of maternal death. $99 \%$ of these maternal deaths occur in developing countries. Similarly, $99 \%$ of the estimated 4 million annual neonatal deaths occur in developing countries
(WHO, 2004). In Egypt, the maternal mortality from infection was $8 \%$ among women in reproductive age. So, the study was conducted to evaluate nurse's compliance with infection control measures in delivery room at Damietta city hospitals (Abed El-Menem, 2007).

\section{Aim}

To evaluate the nurse's compliance with infection control measures in delivery room

\section{Research Questions}

- Were nurses complying with infection control measures in delivery room correctly?

- What are the barriers that prevent nurses to comply with infection control measures in delivery room?

\section{RESEARCH METHODOLOGY}

\section{Research design}

\section{An exploratory study designs}

\section{Setting}

The present study was carried out at four hospitals in Damietta governorate namely: El-Azhar University Hospital, Damietta General Hospital, El-Aser Hospital, Kafr Saad Hospital. The previous mentioned settings were chosen because it's the largest public hospitals which introduce a wide range of maternity services, having higher rate of vaginal delivery and having higher number of nurses working in delivery room.

\section{Subject}

All of the 51 nurses on duty provide care during vaginal delivery in previous mentioned settings.

\section{Study Period}

The study was conducted from August 2016 and extended up to February 2017 in the targeted hospitals.

\section{Tools of data collection}

Tool 1: Self-administer questioners which included 2 parts:

PartA:

General characteristics of the studied nurses e.g. age, educational level, job, years of experience, attending clinical teaching programs related to infection control 
measures 5 questions.

\section{Part B:}

-The barriers that affect nurses' compliance with infection control measures while providing the clinical care in delivery room (5 questions).

-Each item was scored as the following: correct answer $=(2)$ and incorrect answer $=(1)$.

\section{Tool 2: The second tool is an observational check list:}

An observational check list in English language was used to assess nurses' compliance with infection control measures. It comprised 9 procedures covering the following areas:

1. Hand washing (13 items).

2. Donning sterile gloves (13 items).

3. Donning sterile gown (8 items).

4. Masking (11 items).

5. Intramuscular injection (19 items).

6. Perineal care (17 items).

7. Recapping technique for used needle (11items).

8. Instrument and equipment (45items).

Each item was scored as the following: correct practice $=($ comply $)$ and incorrect practice $=($ not comply $)$.

\section{Tool 3: Modified likert scale:}

It was used to assess nurses' attitude regarding compliance of infection control measures in delivery room. The scale consisted of (14) statements. The responses were on three points likert scale (agree, uncertain and disagree).

\section{Content validity and Reliability}

To guarantee the content validity of the tool, it was reexamined and approved by board of 5 specialists in health care field; they concurred it with no comments. Inside consistency among the questionnaire items was evaluated 0.88 Cronbach's alpha $(\alpha)$ and it was adequate

\section{Field work}

The data collections began from August 2016 and extended to February 2017. The researcher visited the previously mentioned study setting three days per week. The researcher obtained the approval to attend and interview nurses, from the director of the hospital and also from the nursing director.

\section{Pilot study}

A pilot study was carried out on (5 nurses), ten percent of total sample were working in delivery unit. The pilot study was conducted to test the relevance and applicability of the assessment sheet, to determine the time needed to finish the sheet and find out if any problem existed that can interfere with the process of data collection. After conducting the pilot study, it was found that the sentences of tool were clear, relevant and applicable. Only few words have been modified.

\section{Ethical Considerations}

An official agreement was granted by submission of an official letter from the Faculty of Nursing to the leaders of the study setting to acquire their permission for data collection. The aim of the study was explained to the nurses to gain the nurses' confidence and trust. Informing them about the study tools it was explained that the tools would neither embarrass their modesty nor will it cause any harm to them. Oral consent was taken from each nurse to participate in the study and the nurses were assured about confidentialities of data collected. The researcher emphasized that the participation is voluntary.

\section{Statistical analysis}

After collection of data, it was revised, coded, and fed to statistical software SPSS version 16. The statistical analysis used T test with alpha error $=0.05$. Microsoft office excel software was used to construct the needed graphs.

\section{Data analysis}

After data control was done all numeric information were communicated within a frame of extend (least to most extreme), cruel and standard deviation (SD). Categorical data were communicated within shape of frequencies and percentages.

\section{Level of significance}

The $p$-value $<0.05$ indicates significant results.

\section{RESULTS}

Table 1 shows that the higher percentage of nurses $(76.5 \%)$ in the study group was in the age group between 26-30 or more with a mean age of $27.8 \pm 4.8$, only $3.9 \%$ of them below 20 years old Meanwhile, majority of them had secondary level of education (diploma), only two of them had bachelor nurse $(84.3 \%$, 
$3.9 \%$ respectively). Moreover, most of them hadn 't a periodical examination before or during work, hadn`t any training course and are living in rural areas $(84.3 \%$, $23.5 \%, 52.9 \%$ respectively). But only about one third of them had vaccine against viral hepatitis $(29.4 \%)$.

Table 1: Characteristics of the studied nurses $(n=51)$

\begin{tabular}{|c|c|c|}
\hline General Characteristics & Frequency & $\%$ \\
\hline \multicolumn{3}{|l|}{ Age (years) } \\
\hline - $\quad<20$ & 2 & 3.9 \\
\hline - $\quad 21-25$ & 10 & 19.6 \\
\hline - $\quad 26-30$ or more & 39 & 76.5 \\
\hline Mean \pm SD & 27.8 & \\
\hline \multicolumn{3}{|l|}{ Educational level } \\
\hline - Diploma nurse & 43 & 84.3 \\
\hline - Technical nurse & 6 & 11.8 \\
\hline - Bachelor nurse & 2 & 3.9 \\
\hline \multicolumn{3}{|l|}{ Years of experience } \\
\hline - $\quad>1$ Year & 5 & 9.8 \\
\hline - $\quad 2-5$ Year & 3 & 5.9 \\
\hline - $\quad>6$ Years & 43 & 84.3 \\
\hline \multicolumn{3}{|l|}{ Training course } \\
\hline - $\quad$ Yes & 39 & 76.5 \\
\hline - $\quad$ No & 12 & 23.5 \\
\hline \multicolumn{3}{|l|}{ Place of residence } \\
\hline - $\quad$ Rural & 27 & 52.9 \\
\hline - Urban & 24 & 47.1 \\
\hline \multicolumn{3}{|c|}{ Vaccination against viral hepatitis } \\
\hline - $\quad$ Yes & 15 & 29.4 \\
\hline - $\quad$ No & 36 & 70.6 \\
\hline \multicolumn{3}{|c|}{ Periodical examination before and during work } \\
\hline - $\quad$ Yes & 8 & 15.7 \\
\hline - $\quad$ No & 43 & 84.3 \\
\hline
\end{tabular}

Table 2 demonstrates the nurses' compliance with infection control measures in delivery room related to hand hygiene. Most of them did not comply to hand hygiene. About $98 \%$ did not turn on water using foot paddle or faucet, $92.2 \%$ did not clean under finger nails and re-soap, rewash and re-rinse hands if heavily contaminated and $88 \%$ did not adjust temperature and running water.
Table 2: Frequency distribution of studied sample 's concerning compliance with hand hygiene in delivery $\operatorname{room}(n=51)$

\begin{tabular}{|l|l|l|l|l|l|}
\hline \multirow{2}{*}{ Hand washing } & \multicolumn{2}{|c|}{ Comply } & \multicolumn{3}{c|}{$\begin{array}{c}\text { Not } \\
\text { comply }\end{array}$} \\
\cline { 2 - 6 } & No & $\%$ & No & $\%$ \\
\hline - Hand washing procedure & 23 & 45.1 & 28 & 54.4 \\
\hline - Running water -paper towels & 22 & 43.1 & 29 & 56.9 \\
\hline - Trash basket & 11 & 21.6 & 40 & 78.4 \\
\hline Procedure & \multicolumn{5}{|l|}{} \\
\hline - Stand in front of but away from sink & 10 & 19.6 & 41 & 80.4 \\
\hline $\begin{array}{l}\text { - Turn on water using foot paddle } \\
\text { or faucet }\end{array}$ & 1 & 2 & 50 & 98 \\
\hline - Adjust temperature, running water & 6 & 11.8 & 45 & 88.2 \\
\hline - Place a small amount of soap & 24 & 47.1 & 27 & 52.9 \\
\hline - Rub vigorously using firm circular & 15 & 29.4 & 36 & 70.6 \\
\hline $\begin{array}{l}\text { - Wash your hand for at least 10-15 } \\
\text { seconds }\end{array}$ & 22 & 43.1 & 29 & 56.9 \\
\hline - Clean under finger nails & 5 & 9.8 & 46 & 90.2 \\
\hline $\begin{array}{l}\text { - Rinse your hand under running water } \\
\text { keep finger pointed sound }\end{array}$ & 23 & 45 & 28 & 54.2 \\
\hline $\begin{array}{l}\text { - } \quad \text { Re-soap your hand, rewash and } \\
\text { rerinse if heavily contaminated }\end{array}$ & 4 & 7.8 & 47 & 92.2 \\
\hline
\end{tabular}

Table 3 shows the distribution of the studied nurses according to level hand washing checklist. Most of the studied sample does not comply with hand washing.

\section{Table 3: Distribution of the studied nurses according to level hand washing checklist $(n=51)$}

\begin{tabular}{|c|c|c|}
\hline Hand washing & No. & $\%$ \\
\hline \multicolumn{2}{|c|}{ Hand washing checklist } & 5.9 \\
\hline$=80$ comply & 3 & 94.1 \\
\hline$<80$ not comply & 48 & \\
\hline Total score & $0.0-10.0$ \\
\hline Min. - Max. & $3.25 \pm 3.74$ \\
\hline Mean \pm SD. & \\
\hline Percent score & $0.0-83.33$ \\
\hline Min. - Max. & $27.12 \pm 31.13$ \\
\hline Mean \pm SD.
\end{tabular}

In Table 4 it is noticed that nurses' compliance with infection control measures in delivery room related to wearing personal protective equipment did not comply regarding gowning and masking $(92.2 \%$ and $72.5 \%$ respectively). Nearly all of them (98\%) showed comply in gloving. 
Table 4: Frequency Distribution Concerning Studied Sample's Compliance to Infection Control Measures in Delivery Room Related to Wearing Personal Protective Equipment (n=51)

\begin{tabular}{|l|l|l|l|l|}
\hline \multirow{2}{*}{ Protective equipment } & \multicolumn{2}{|l|}{ Comply } & \multicolumn{2}{l|}{ Not comply } \\
\cline { 2 - 5 } & No & $\%$ & No & $\%$ \\
\hline Gloving & 50 & 98 & 1 & 2 \\
\hline Gowning & 4 & 7.8 & 47 & 92.2 \\
\hline Masking & 14 & 27.5 & 37 & 72.5 \\
\hline
\end{tabular}

Table 5 demonstrates nurses' distribution according to intramuscular injection checklist. It revealed that $82.4 \%$ complied with the process of preparing appropriate syringe and injects medication properly. $80.4 \%$ of them prepared medication and withdrew needle and released retreated skin. On the other hand, only $9.8 \%$ and $5.9 \%$ of them wash their hand and cleans site with antimicrobial wipe.

Table 5: Distribution of the Studied Nurses According to Intramuscular Injection Checklist $(n=51)$

\begin{tabular}{|l|c|c|c|c|}
\hline \multirow{2}{*}{} & \multicolumn{2}{|c|}{ Not comply } & \multicolumn{2}{c|}{ Comply } \\
\cline { 2 - 5 } & No. & $\%$ & No. & $\%$ \\
\hline Preparing Equipment & 9 & 17.6 & 42 & 82.4 \\
\hline Appropriate syringe & 43 & 84.3 & 8 & 15.7 \\
\hline Injection needle & 10 & 19.6 & 41 & 80.4 \\
\hline Medication & 48 & 94.1 & 3 & 5.9 \\
\hline Antimicrobial swabs. & 36 & 70.6 & 15 & 29.4 \\
\hline Gloves & 23 & 45.1 & 28 & 54.9 \\
\hline Puncture resistant container. & 29 & 56.9 & 22 & 43.1 \\
\hline Procedure & 43 & 84.3 & 8 & 15.7 \\
\hline Provide privacy & 29 & 56.9 & 22 & 43.1 \\
\hline Wash hands and don gloves. & 49 & 96.1 & 2 & 3.9 \\
\hline Place client in prone position, if possible. & \multicolumn{4}{|l}{} \\
\hline Cleans site with antimicrobial wipe. & 48 & 66.7 & 17 & 33.3 \\
\hline $\begin{array}{l}\text { Pull skin 1: 1 1/2 inch laterally away } \\
\text { from injection site of spread tissue as } \\
\text { indicated. }\end{array}$ & 34 & & 3 & 5.9 \\
\hline $\begin{array}{l}\text { Maintain displacement and insert } \\
\text { needle at 90 angles. }\end{array}$ & 18 & 35.3 & 33 & 64.7 \\
\hline $\begin{array}{l}\text { Aspirate by pulling back on planer } \\
\text { to see if needle is blood vessel if so } \\
\text { discards and prepare new injection. }\end{array}$ & 43 & 84.3 & 8 & 15.7 \\
\hline Inject medication properly. & 9 & 17.6 & 42 & 82.4 \\
\hline $\begin{array}{l}\text { Withdraw needle and release retreated } \\
\text { skin. }\end{array}$ & 10 & 19.6 & 41 & 80.4 \\
\hline $\begin{array}{l}\text { Apply light pressure with swab. } \\
\text { Do not massage. }\end{array}$ & 46 & 78.4 & 11 & 21.6 \\
\hline $\begin{array}{l}\text { Apply light pressure to the syringe } \\
\text { with uncapped needle still attached } \\
\text { into puncture resistant container. }\end{array}$ & 16 & 31.4 & 35 & 68.6 \\
\hline Remove gloves. & 40.2 & 5 & 9.8 \\
\hline Wash hand. & \multicolumn{2}{|l}{} \\
\hline
\end{tabular}

Table 6, 7 shows the distribution of the studied nurses according to perineal care checklist. It denotes that about $74.5 \%$ of them comply with the procedure of preparing equipment like clean gloves but sponges or cotton ball were not prepared by $94 \%$ of nurses. $92.2 \%$ explain procedure to care woman, wash hands before and after each perineal care was not done-by $8.3 \%$, concerning total perineal care compliance most of them $92.2 \%$ did not comply (Table 7).

\section{Table 6: Distribution of the Studied Nurses According to Perineal care Checklist $(n=51)$}

\begin{tabular}{|c|c|c|c|c|}
\hline & \multicolumn{2}{|c|}{ Not comply } & \multicolumn{2}{|c|}{ Comply } \\
\hline & No. & $\%$ & No. & $\%$ \\
\hline \multicolumn{5}{|l|}{ Preparing Equipment: } \\
\hline Clean gloves. & 13 & 25.5 & 38 & 74.5 \\
\hline A sterile perineal pad. & 17 & 33.3 & 34 & 66.7 \\
\hline Mackintosh. & 16 & 31.4 & 35 & 68.6 \\
\hline Warm antiseptic solution. & 14 & 27.5 & 37 & 72.5 \\
\hline Sponges or cotton ball. & 16 & 31.4 & 35 & 68.6 \\
\hline Bed pan. & 48 & 94.1 & 3 & 5.9 \\
\hline \multicolumn{5}{|l|}{ Procedure } \\
\hline Explain procedure to woman. & 47 & 92.2 & 4 & 7.8 \\
\hline $\begin{array}{l}\text { Provide privacy by closing door and } \\
\text { pulling drape. }\end{array}$ & 27 & 52.9 & 24 & 47.1 \\
\hline $\begin{array}{l}\text { Wash hands before and after each } \\
\text { perineal care. }\end{array}$ & 43 & 84.3 & 8 & 15.7 \\
\hline $\begin{array}{l}\text { Position and drape according to } \\
\text { procedure. }\end{array}$ & 16 & 31.4 & 35 & 68.6 \\
\hline $\begin{array}{l}\text { Place mackintosh and bedpan under the } \\
\text { client's hips. }\end{array}$ & 16 & 31.4 & 35 & 68.6 \\
\hline Don gloves. & 13 & 25.5 & 38 & 74.5 \\
\hline $\begin{array}{l}\text { Lift corner of drape away from perineal } \\
\text { area. }\end{array}$ & 33 & 64.7 & 18 & 35.3 \\
\hline $\begin{array}{l}\text { Remove soiled pad from front to back, } \\
\text { discard }\end{array}$ & 13 & 25.5 & 38 & 74.5 \\
\hline $\begin{array}{l}\text { Pat dry, use each sponge onetime, pat } \\
\text { from front to back. Then discard sponges. }\end{array}$ & 19 & 37.3 & 32 & 62.7 \\
\hline $\begin{array}{l}\text { Always do perineal care after voiding } \\
\text { stool, before and after episiotomy. }\end{array}$ & 50 & 98.0 & 1 & 2.0 \\
\hline
\end{tabular}

Table 7: Distribution of the Studied Nurses According to Perineal Care Checklist

\begin{tabular}{|c|c|c|}
\hline & No. & \% \\
\hline Level Perineal care checklist & & 92.2 \\
\hline$<80$ comply & 47 & 7.8 \\
\hline$\geq 80$ not comply & 4 & \\
\hline Total score & \multicolumn{2}{|c|}{$0.0-16.0$} \\
\hline Min. - Max. & \multicolumn{2}{|c|}{$8.78 \pm 5.50$} \\
\hline Mean \pm SD. & \multicolumn{2}{|c|}{$0.0-94.12$} \\
\hline Percent score & \multicolumn{2}{|c|}{$51.67 \pm 32.35$} \\
\hline Min. - Max. & \multicolumn{2}{|c|}{} \\
\hline Mean \pm SD. & \multicolumn{2}{|c|}{} \\
\hline
\end{tabular}


Table 8 shows the distribution of the studied nurses according to total compliance with infection control measures in delivery room. It demonstrates that none of them comply with overall infection control measures in delivery room.

Table 8: Distribution of the Studied Nurses According to Total Compliance with Infection Control Measures in Delivery $\operatorname{Room}(n=51)$

\begin{tabular}{|l|l|l|}
\hline Total compliance & No. & \% \\
\hline Practice items overall & 51 & 100.0 \\
\hline$<80$ not comply & 0 & 0.0 \\
\hline$\geq 80$ comply & \multicolumn{2}{|l|}{} \\
\hline Total score & $0.0-107.0$ \\
\hline Min. - Max. & $42.25 \pm 18.66$ \\
\hline Mean \pm SD. & \multicolumn{2}{|l|}{} \\
\hline Percent score & $0.0-78.68$ \\
\hline Min. - Max. & $31.07 \pm 13.72$ \\
\hline Mean \pm SD. &
\end{tabular}

Table 9 shows the relation between nurses' practice and their general characteristics, it shows statistically significant $\left(0.05^{*}\right)$ among nurses in age, educational level, year of experience, training course, residence, and vaccination against viral hepatitis and comply with infection control measure.

Table 9: Relation between Nurses'Practice and their General Characteristics

\begin{tabular}{|c|c|c|c|c|c|c|c|}
\hline \multirow{2}{*}{\multicolumn{2}{|c|}{ Personal character }} & \multicolumn{2}{|c|}{ Incorrect } & \multicolumn{2}{|c|}{ Correct } & \multirow[t]{2}{*}{$X^{2}$} & \multirow{2}{*}{$\begin{array}{c}P- \\
\text { value }\end{array}$} \\
\hline & & No & $\%$ & No & $\%$ & & \\
\hline \multirow{3}{*}{ Age in years } & $<20$ & 1 & 1.9 & 1 & 1.9 & \multirow[t]{3}{*}{15.56} & \multirow{3}{*}{$<0.001$} \\
\hline & $21-25$ & 9 & 17.6 & 1 & 1.9 & & \\
\hline & $\begin{array}{l}26-30 \text { or } \\
\text { more }\end{array}$ & 37 & 72.9 & 2 & 3.8 & & \\
\hline \multirow{3}{*}{$\begin{array}{l}\text { Educational } \\
\text { qualification }\end{array}$} & Diploma & 41 & 80.6 & 2 & 3.8 & \multirow[t]{3}{*}{5.86} & \multirow[t]{3}{*}{$<0.05$} \\
\hline & Technical & 5 & 9.9 & 1 & 1.9 & & \\
\hline & Bachelor & 1 & 1.9 & 1 & 1.9 & & \\
\hline \multirow{3}{*}{$\begin{array}{l}\text { Years of } \\
\text { experience }\end{array}$} & $>1$ Year & 4 & 7.9 & 1 & 1.9 & \multirow[t]{3}{*}{7.62} & \multirow[t]{3}{*}{$<0.05$} \\
\hline & 2-5 Year & 2 & 3.8 & 1 & 1.9 & & \\
\hline & $>6$ Years & 40 & 78.6 & 3 & 5.9 & & \\
\hline \multirow{2}{*}{$\begin{array}{l}\text { Training } \\
\text { course }\end{array}$} & Yes & 6 & 11.9 & 2 & 3.8 & \multirow[t]{2}{*}{13.65} & \multirow[t]{2}{*}{$<0.05$} \\
\hline & No & 40 & 78.4 & 3 & 5.9 & & \\
\hline \multirow[t]{2}{*}{ Residence } & Rural & 25 & 49.1 & 2 & 3.8 & \multirow[t]{2}{*}{4.32} & \multirow[t]{2}{*}{$<0.05$} \\
\hline & Urban & 21 & 41.2 & 3 & 5.9 & & \\
\hline \multirow{2}{*}{$\begin{array}{l}\text { Vaccination } \\
\text { against viral } \\
\text { hepatitis }\end{array}$} & Yes & 14 & 27.5 & 1 & 1.9 & \multirow[t]{2}{*}{9.81} & \multirow[t]{2}{*}{$<0.05$} \\
\hline & No & 34 & 62.7 & 4 & 7.9 & & \\
\hline
\end{tabular}

Figure 1 shows the total Level of Intramuscular Injection Checklist. About $98.0 \%$ of them do not comply with intramuscular injection.

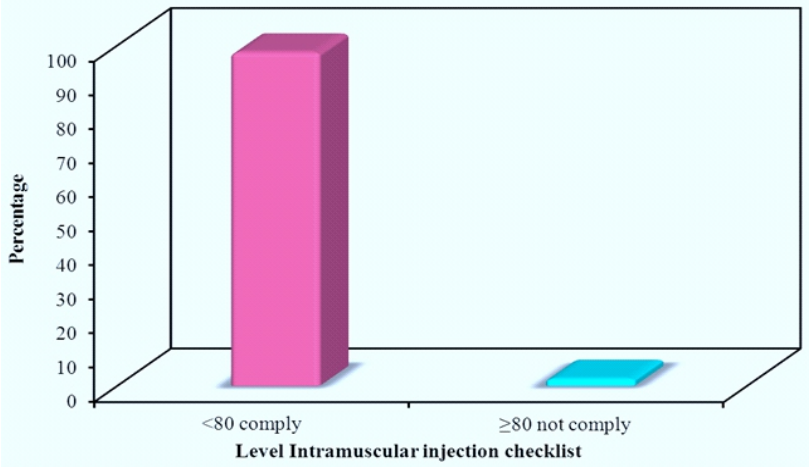

Figure 1: Intramuscular Injection Checklist $(n=51)$

Figure 2 displays the results of barriers of nursing noncompliance with infection control measures. It points to emergency, lack of equipment and supplies, lack of infection control measures, lack of periodical infection and control training course were the most barriers $(37.5 \%, 87.5 \%, 75$ and $95 \%$ respectively).

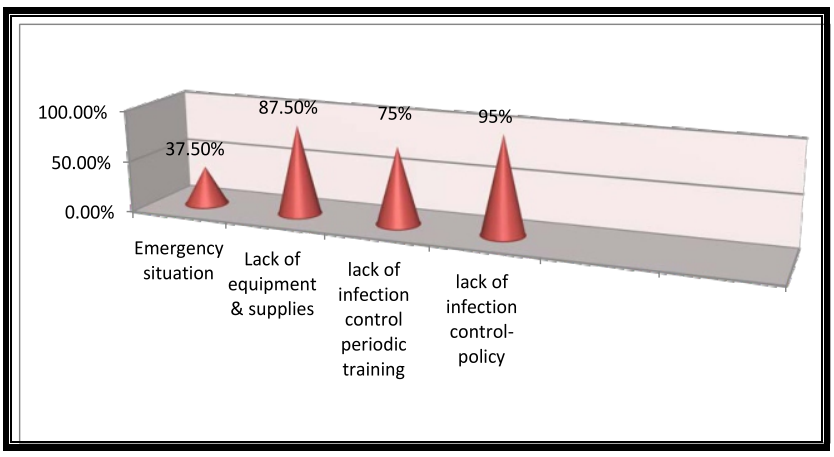

Figure 2: Barriers of Nursing Noncompliance with Infection Control Measures

\section{DISCUSSION}

It was demonstrated from the present study finding that the higher percentage of nurses was in the age between 26-30 or more with a mean age of $27.8 \pm 4.8$, Meanwhile, majority of them had secondary level of education (diploma), only two had bachelor nurse. 
More than half of them had 6 years of experience. These finding were disagreed by Al Rawajfah Hweidi \& Alkhalaileh, (2013) who reported that more than half of the nurses had Bachelors degree and the majority of nurses were less than 23 years old and more than half of them had secondary graduation. This may be due to difference in the place of study and the different personal characteristics of the studied group in the study sample.

Chastre (2004), mentioned that joining infection control training programs not only improve practices and aid in correct-usage of resources but correspondingly contributes to nurses' profile although. Infection control education is the responsibility of the individuals, it should be supplemented and facilitated by specialized infection control staff.

In this regards our finding showed that more than the half of nurses did not atttend any previous training course related to infection prevention and control. This result was in agreement with Ghoneim, (2011) and Hassan, (2011), they documented that the majority of nurses did not attend any training programs because the organization did not arrange any upgrading programs for nurses about infection control measures, they were busy in excessive unit work or had personal factors that prevented them to attend the training course, such as marriage and children .

Furthermore, the results of the current study showed that, above three quarters of nurses did not attend any pre-employment screening tests and periodic examination during the work, this increased risk of spread of infection, absenteeism and disability . This finding was in accordance with Ghoneim, (2011) who reported that, the majority of studied group had no preemployment screening tests and periodic examination during the work. So, the nurses should monitor and investigate every potentially harmful infectious exposure and the outbreak of infection among personnel and identify the infection risk factors related to employment.

Regarding immunization against viral hepatitis, in our study, two third of nurses were not immunized against viral hepatitis this doesn't comply with the national standard of infection prevention control. These findings are also consistent with (Damani, 2004) who mentioned that nurses should be vaccinated to prevent the potential infection of Hepatitis B virus (HBV). The nurses are at risk of infection with hepatitis because they are frequently exposed to blood and other body fluids during the daily activities. So, routine immunization of nurses against infection with $\mathrm{HBV}$ is an effective way to protect them and the patients as well as the community (Yacoub et al., 2010).

Regarding assessing nurses' compliance with hand washing, the current study showed that the hand hygiene compliance was low. These results agree with Yawson \& Hesse, (2013) who reported that, the hand hygiene compliance among doctors and nurses was low. Similarly Pettit, (2008) reported that the compliance with hand hygiene practice falls despite a fairly high awareness of its importance. Also Jarvis, Brachman \& Bennett, (2007) revealed that hand washing technique is inadequate and often not carried out at in all nursing procedures.

Additionally, Beder \& Michel, (2004) reported that the main cause of spread of infection is inadequate hand washing by the staff who also reported that the majority of nurses did not wash their hands before and after patient contact, good hand washing technique is an essential skill, but many health care workers fail to practice it.

The current study showed that, the nurse's compliance with protective clothes was poor with gloving and noncompliance to masking and gowning. In this respect Timby, (2007) mentioned that putting sterile gloves and changing gloves in between patient care practice reduce or limit risks of cross infection and limit exposure of nurses to blood, this result was disagreed by Zakzouk, (2004) who found that, nurses had a high compliance regarding gowning. This could also be attributed to unavailability and unawareness about the importance of these protective devices. This was also agreed by (Ahmad, Rehan \& Pani, 2013) who stated that the completed compliance with recommended guidelines was reported and over $90 \%$ of the nurses changed gloves between patients.

It was also agreed with Smeltzer \& Bare, (2005) who mentioned that gloves provide an effective barrier for hands from the micro flora associated with patient care. Gloves must be worn when health care worker 
have contact with any patient's secretions or excretion and must be discarded after each patient care contact. On other hand this result was agreed with Picheansathin, (2005), who mentioned that, majority of nurses had unsatisfactory performance regard protective barriers. This may be due to different reasons, for why nurses did not use protective barriers, such as the supplies may not be available, including insufficient time, discomfort, inconvenience habits and belief that universal precaution are not necessary .

For nurses compliance with equipment handling and processing the current study found that all of them did not comply to the process of disinfection by boiling, most of them did not comply to cleaning, chemical \& dry heat, This finding was agreed by (Abed El-Menem, 2007 ) who reveal that, the majority of nurses followed incorrect practice in cleaning contaminated instruments before sterilization. This may be due to inadequate supplies, lack of knowledge of different disinfection step, absolute lack of respect about the handling of disposable material and the elaboration of the correct procedures. This leads to ineffective sterilization or disinfection and lead to spread of infection. On other hand these results disagreed with the work of RöhmRodowald et al., 2012) who stated that, effective decontamination of instruments is a key element of infection control.

Concerning the third research question were" what were the barriers that prevent nurses' to comply with infection control measures in the delivery room?"

The results of the present study revealed that, the main reasons of nursing noncompliance with infection prevention measures were lack of periodical infection control training courses and inadequate supplies and equipment as well as lack of infection control committee and emergency situations in obstetric unit. These findings were in parallel with Abed El-Menem, (2007) who studied assessment of infection control measures practiced by nurses in the labor and delivery unit reported some obstacles that hindered the application and compliance to infection control measures practiced by nurses such as inadequate supplement, absence of the infection control team for guidance and supervision and no training session.
This study has concentrated on those barriers that affect compliance negatively leading to noncompliance. Many of the emerged factors, contributing to noncompliance, are in accordance with findings of previous study by Kermode et al., (2005) who studied compliance with Universal Precautions (UP) in India.

There are several studies that reveal that numerous times there are time limitations to execute safety measures. They detailed that due to overwhelming workload, there's no time to follow the rules. In expansion, managing a critical circumstance was too considered as a hindrance in actualizing standard safeguards. It was clarified that a crisis circumstance it requires doing several things at the same time, exceptionally quickly and usually under overwhelming pressure. In the present circumstances it is seen that time constrain may cause hindrance in the adherence to infection control measures for the medical caretakers (Oliveira, Cardoso \& Mascarenhas, 2010).

\section{CONCLUSION}

In the light of the main study findings, it can be concluded that, the nurses compliance to infection control was poor. This throws light on their total knowledge, practice and negative attitude. Although they face a lot of barriers that hinder them to comply with infection control measures such as emergency situation, lack of equipment and supplies, lack of infection control measures, lack of periodical infection and control training course.

\section{RECOMMENDATIONS}

1. It's necessary pre-employment screening tests for nurse's obligatory hepatitis vaccinations for all nurses.

2. Strategic plan to overcome obstacles and barriers that hinder nurses to compliance with infection control measures.

3. It's essential to consider the national standards of infection prevention adopted by the ministry of health in delivery room of all hospital in Damietta governorate.

4. Consulting with nurses to identify system problems.

5. Providing education and training on the correct use of equipment.

6. Consulting with nurses to identify problems of the system. 


\section{REFERENCES}

Abed El-Menem, O. (2007). Assessment of Infection Control Measures Practiced by Nurses in the Labour and Delivery Unit. Master Thesis at Faculty of Nursing, Benha University, Egypt.

Ahmad, I.A., Rehan, E.A. \& Pani, S.C. (2013). Compliance of Saudi dental students with infection control guidelines. International Dental Journal, 63(4), pp 196-201.

Ahmed, A. (2015). Assessment of measurements of infection control in the Labor Room at Omdurman Maternity Hospital in 2014-2015. AlzaeimAlazhari University, Sudan.

Al-Rawajfah, L.M., Hweidi, M. \& Alkhalaileh, Y. S. (2013). Compliance of Jordanian Registered Nurses with Infection Control Guidelines: A National Population-Based Study. American Journal of Infection Control, 41(11), pp 1065-1068.

Beder, N.A. \& Michel, H.W., (2009). Impact of university infection control intervention program for nurses. Assiut Scientific Nursing Journal, 2(1), pp 13-26.

Damani, N.N. (2004). Manual of Infection Control Procedures. $1^{\text {st }}$ Edition, Greenwich Medical Media Ltd, London, chap 1x.p.,pp 132-126.

Friedman, N., Carmeli, Y., Walton, A. \& Schwaber, M. (2017). Carbapenem-resistant Entero-bacteriaceae: a strategic roadmap for infection control. Infection Control and Hospital Epidemiology, 38(5), pp 580-594.

Ghonaiem, S. (2011). Impact of a Designed Infection Control Training Program on Nurses Knowledge and Practices at Intensive Care Unit, Benha University Hospital. Doctorate, Thesis, Faculty of Nurses, Benha University, Egypt.

Hassan, H. (2011). Nursing Performance Regarding Infection Control for Patient Undergoing Open Heart Surgery. Master Thesis, Faculty of Nursing, Benha University, Egypt.

Hazavehei, S., Taghdisi, M. \& Saidi, M. (2011). Application of the Health Belief Model for osteoporosis prevention among middle school girl students, Garmsar, Iran. Educ Health(Abingdon), 20(1), 23.

Jarvis, W.R., Brachman, P.S. \& Bennett, J. (2007). Bennett \& Brachman's Hospital Infections. $5^{\text {th }}$ edition, Lippincott Williams \& Wilkins, Philadelphia.

Kaïret, K., Ho, E., Van Kerkhoven, D., Boes, J., Van Calenbergh, S., Pattyn, L. \& Lemay, P. (2017). USA300, A strain of community-associated methicillin-resistant Staphylococcus aureus, crossing Belgium's borders: outbreak of skin and soft tissue infections in a hospital in Belgium. European Journal of Clinical Microbiology \&Infectious Diseases, 36(5), pp 905-909.

Kermode, M., Jolley, D., Langkham, B., Thomas, M. S., Holmes, W. \& Gifford, S. (2005). Compliance with Universal/Standard Precautions among health care workers in rural north India. American Journal of Infection Control, 33(1), pp 27-33.

Morgan, D.J., Wenzel, R.P. \& Bearman, G. (2017). Contact precautions for endemic MRSA and VRE: time to retire legal mandates. Jama, 318(4), pp329-330.

Oliveira, A., Cardoso, C. \& Mascarenhas, D. (2010). Contact Precautions in Intensive Care Units: Facilitating and Inhibiting Factors for Professionals'Adherence. Revista da Escola de Enfermagem da USP, 44(1), pp 161-165.

Pettit, T. (2008). Improving Compliance with Hand Hygiene in Hospitals. Infection Control and Hospital Epidemiology, 21(11), pp 381-386. 
Picheansathian, W. (2005). Compliance with universal precautions by emergency room nurses at Maharaj Nakorn Chiang Mai Hospital. Journal of the Medical Association of Thailand, 78 (suppI2), pp 118-1122.

Röhm-Rodowald, E., Jakimiak, B., Chojecka, A., Zmuda-Baranowska, M. \& Kanclerski, K. (2012). Assessment of contamination processes: cleaning, disinfection and sterilization in dental practice in Poland in the years 20112012. Przegląd Epidemiologiczny, 66(4), pp 635-641.

Sax, H., Perneger, T. \& Hugonnet, S. (2011). Knowledge of standard and isolation precautions in a large teaching hospital. Infection Control and Hospital Epidemiology, 26(3), pp 298- 304.

Singh, A., Purohit, B., Bhamba, A., Saxena, S., Singh, A. \& Gupta, A. (2011). Knowledge, attitudes, and practice regarding infection control measures among dental students in Central India. Journal of Dental Education, 75(3), pp 421-427.

Smeltzer, S.C. \& Bare, B.G. (2002). Brunner and Suddarth's Textbook of Medical-Surgical Nursing. $9^{\text {th }}$ Edition. Lippincott Williams \& Wilkins, Philadelphia, United States.

Tait, A.R., Voepel-Lewis, T., Tuttle, D.B. \& Malviya, S. (2011). Compliance With Standard Guidelines for the Prevention of Occupational Transmission of Bloodborne and Airborne Pathogens: A Survey of Postanesthesia Nursing Practice. Journal of continuing Education in Nursing, 31(1), pp 38-44.

Tmiby B.K. (2007). Fundamental Skills and Concepts in Patient Care. Revised Reprint, $7^{\text {th }}$ edition, Lippincott Williams \& Wilkins, Philadelphia.

World Health Organization (2004). Practical guidelines for infection control in health care facilities. Regional Office for the Western Pacific. Manila: WHO Regional Office for the Western Pacific. Retrieved from: http://www.who.int/iris/handle/10665/206946.

Yang, Y.L., Ko, E.W.C., Chen, Y.R. \& Huang, C.S. (2018). Does Sensory Retraining Improve Subjective Rating of Sensory Impairment after Bilateral Sagittal Split Osteotomy? Plastic and Reconstructive Surgery - Global Open, 6(5), e1769.

Yacoub, R., Al Ali, R., Moukeh, G., Lahdo, A., Mouhammad, Y. \& Nasser, M. (2010). Hepatitis B Vaccination Status and Needlestick Injuries among Healthcare Workers in Syria. Journal of Global Infectious diseases, 2(1), pp 28-34.

Yawson, A. \& Hesse, A. (2013). Hand Hygiene Practices and Resources in a Teaching Hospital in Ghana. The Journal of Infection in Developing Countries, 17(4), pp 338-347.

Zakzouk, M. (2004). Infection Standards in Burn Unit. Doctorate Thesis Faculty of Nursing, Ain Shams University, Cairo, Egypt. 